\title{
Marcas, puntos y trazados en el Mar Caribe colombiano ${ }^{1}$
}

\author{
Fabian Enrique Leotteau ${ }^{2}$ \\ Universidad de Caldas, Colombia \\ (iD) https://orcid.org/0000-0002-2711-0192
}

Resumen: El presente artículo expone cómo los pescadores artesanales de Old Providence, La Boquilla y Taganga, apoyados en su «conocimiento empírico», crean marcas o puntos para navegar y pescar en el mar Caribe colombiano sin usar el GPS. El piloto de la lancha, con su «sentido común» y su experiencia ancestral en navegación, crea una carta de navegación en su mente para ir a pescar. Esta carta de navegación tiene como referencia puntos o marcas fijas en la playa, los cuales son usados como coordenadas que se unen en un plano en movimiento en el mar Caribe para su desplazamiento. La metodología etnográfica, a partir de las entrevistas, su contexto y la imagen de los propios pescadores, muestra el proceso de extracción de la imagen de la mente de los pescadores con el fin de hacerla visible a ellos y a la comunidad. Esas imágenes analizadas y recreadas son las que permiten visualizar los dibujos mentales de los pescadores después de que son verificados a través de photo-elicitation y, luego, trasladados a una plataforma digital. Esto permite concluir que la experiencia de revelar los mapas mentales de los pescadores artesanales, a través de dibujos en tinta y grafito sobre papel, y luego transferidos a una plataforma digital, evidencia una nueva mirada sobre las cartas de navegación y las historias orales visualizadas en un mar digital.

Palabras clave: conocimiento empírico; marcas; patrimonio ideológico; dibujos digitales; imagen etnográfica.

Recibido: 27/07/2019 | Aceptado: 23/01/2020 | Disponible en línea: 21/08/2020

Cómo citar este artículo: Leotteau, F.E. (2020). Marcas, puntos y trazados en el mar Caribe colombiano. Jangwa Pana, 19 (3), 452 - 475. Doi: https://doi.org/10.21676/16574923.3652

\footnotetext{
Abstract: This article explains how the traditional fishermen of Old Providence, La Boquilla and Taganga, use "empirical knowledge" to create marks or points to navigate and fish in the Colombian Caribbean Sea without using GPS. The pilot of the boat, with "common sense" and ancestral experience, creates a mental navigation route to go fishing. This navigation map has reference marks or fixed points on the beach used as coordinates which unite in the moving plane that is the Caribbean Sea, allowing for travel. The ethnographic methodology, from interviews, context and information collected, demonstrates the process of extracting the

${ }^{1}$ El presente artículo de Investigación es producto de mi tesis doctoral "Mapas mentales de pescadores artesanales en el Mar Caribe colombiano" bajo la asesoría del PhD Heitor Alvelos. Asimismo, manifiesto que no ha sido publicado con anterioridad, ni tengo conflicto de intereses. El proyecto de investigación ha sido financiado en su totalidad con presupuesto ajustado del autor, para cumplir los objetivos trazados. Además, la investigación es independiente de las instituciones donde he estudiado y donde trabajé. La redacción del manuscrito se realizó sólo con interés concerniente al ejercicio investigativo. Debo decir que, durante la investigación doctoral he presentado avances científicos como estudiante del doctorado en Diseño y Creación en seminarios, congresos, encuentros y, en el marco del Festival de la Imagen, en la Universidad de Caldas, evento internacional enfocado en las ciencias, las artes y las nuevas tecnologías en Manizales Colombia.

${ }^{2}$ Correo electrónico: leotteau1@gmail.com.
} 
image from the mind of the fisherman to make it visible to the fishermen as well as to the community. These analyzed and recreated images, verified through photo-elicitation, allow the mental drawings of the fishermen to be seen and are then transferred to a digital platform. In conclusion: the experience of revealing the mental maps of artisanal fishermen, through drawings in ink and graphite on paper, then transferred to a digital platform, offers a new look at navigation charts and oral stories of fishermen, visualized in a digital sea.

Keywords: empirical knowledge; marks; ideological heritage; digital drawings; ethnographic imaging

\section{Introducción}

Esta investigación tuvo sus inicios en Cartagena de Indias, San Andrés Islas y Providencia, cuando ejecuté la Maestría en Estudios del Caribe en la Universidad Nacional. Allí pude delimitar el contexto del mar territorial del Caribe colombiano, localizado en el extremo noroccidental de Suramérica, el cual limita: al norte, con Jamaica, Haití y República Dominicana; al noroeste, con Nicaragua y Costa Rica; al este, con Venezuela en la zona de Castilletes (N 11o50í W 71o18í) y, al oeste, con Panamá en la zona de Cabo Tiburón (N 08o42í W 77o19í). Según el Instituto de Investigaciones Marinas y Costeras José Benito Vives de Andréis (INVEMAR) (Vives de Andrei, 1993), el mar del Caribe colombiano posee una longitud costera aproximada de $194513 \mathrm{~km}^{2}$, una zona económica de 524981 $\mathrm{km}^{2}$, y ocupa el $11 \%$ de la superficie del país (Garay, 2005). Allí se ubican los pueblos pesqueros de Old Providence, La Boquilla y Taganga. Cada uno de estos pueblos se abordó desde su geohistoria, describiendo su sitiogeografía y la relación con sus ecosistemas, incluyendo manglares (como en La Boquilla) y montañas (como en Taganga). También se identificaron sus corrientes marinas, la dirección de los vientos, el color de sus aguas, así como similitudes y diferencias en cada uno de los pueblos, dos de ellos ubicados a orillas del mar Caribe y uno de ellos (Old Providence) siendo una isla rodeada de varios cayos con unos verdes-azules en sus aguas, cerca de San Andrés Islas.

De igual manera, se identificaron sus habitantes y sus ancestros: los indígenas nativos desde antes de la llegada de los europeos y los africanos traídos en contra de su voluntad, sin olvidar los asiáticos y las distintas migraciones y mezclas culturales que ha recibido el Caribe colombiano, como también las 12 lenguas que aún se hablan en este contexto. Asimismo, las migraciones constantes por el mar territorial del Caribe, producto de rutas comerciales y de la lucha por el territorio desde la época, permitieron que las ciudadespuertos evolucionaran. Ahora bien, se debe mencionar que los indígenas fueron quienes les enseñaron a navegar a los españoles por el mar Caribe, entrando a barlovento y saliendo a sotavento; por ello, la relación comercial entre los tres puertos más importantes en la colonia: Cartagena de Indias, la Habana y Veracruz. También podemos decir que a través de estos puertos se produjeron procesos migratorios desde la colonia, estableciendo mezclas culturales al generar nuevas maneras de ver el contexto.

Es por ello que la investigación se desarrolla en los pueblos pesqueros de La Boquilla, Taganga y Old Providence: cada uno es un laboratorio territorial geoestético, geohistórico y geopolítico, donde se evidencian problemas ambientales, económicos y sociales que, muchas veces, son expresados por sus habitantes en prácticas identitarias culturales, buscando reírse de ellos mismos y hasta burlarse de la muerte en sus relatos y canciones. En efecto, esta fundamentación sobre el contexto, apoyada en la tesis de Maestría de Estudios del Caribe, permitió ubicar geográficamente los pueblos pesqueros de Old 
Providence, La Boquilla y Taganga:

pueblos inicialmente indígenas que fueron marcados por el exterminio, por la esclavitud con la traída de los 'afros' desnudos y en contra de su voluntad, por las mezclas culturales, por el sistema de plantación, la colonización, la descolonización, los conflictos armados por el dominio del territorio (Leotteau, 2011, págs. 23-39).

Cabe agregar que este contexto y su relación con los pescadores artesanales fue el que se abordó en la investigación Mapas mentales de pescadores artesanales del Caribe colombiano (Leotteau, 2018).

Podemos decir que la pesca artesanal ha sido un soporte fundamental en el contexto del mar Caribe colombiano como «estrategia de supervivencia», por lo que es un conocimiento trasmitido oralmente por generaciones. Por consiguiente, el «conocimiento empírico» de los nativos pesqueros les ha permitido adaptarse a su contexto, creando sus propias herramientas con el fin de navegar en un plano en movimiento. A su vez, ese «conocimiento empírico» es usado para la creación de dibujos mentales como herramienta de ubicación y su aplicación en la pesca artesanal. En varias ocasiones me preguntaba: ¿cómo hacen los pescadores artesanales para desplazarse por el mar Caribe sin necesidad de usar GPS? Después de hacer esta pregunta varias veces me encontré con que los pilotos habían aprendido a navegar sin instrumentos sofisticados, haciendo uso de un «conocimiento empírico» transmitido oralmente por sus familiares más cercanos desde mucho tiempo atrás.

Ahora bien, los problemas y necesidades de los habitantes en su contexto hicieron que aprendieran a moverse de una isla a otra. Consecuente a ello, los pescadores veteranos hacen una lectura de los signos naturales aplicando su intuición, por lo que ellos saben identificar la dirección de los vientos, las corrientes marinas y hasta el color del mar. De ahí surge la pregunta-problema de la investigación: ¿De qué manera los pescadores de la Boquilla, Taganga y Old Providence se apoyan en el dibujo mental para ubicarse en el mar Caribe durante la ejecución de la pesca tradicional?, ¿cómo se articulan estos dibujos mentales con los portulanos de la época colonial?, y, ¿existe una relación entre ambos? Estas preguntas motivaron la ejecución de la investigación durante las salidas de campo en la recolección de información, por lo que resultaron muchas preguntas que abrieron otras puertas sobre el sentido de la imagen y como la aplican en su contexto.

Cabe mencionar que la extracción de los dibujos mentales de algunos pescadores fue una experiencia metodológica desde la etnografía de la imagen llevada a soportes de papel. Luego, esas imágenes fueron evaluadas y validadas por los propios pescadores, bajo la metodología photo-elicitation, a fin de confirmar esos dibujos mentales. De ahí resultaron otras preguntas articuladas al análisis de las imágenes para ser llevadas a un soporte digital; es decir, imágenes fijas y videos, los cuales fueron editados en otro soporte para ser visualizados mediante videoclips y fotografías.

En ese orden de ideas, se escogieron estos tres pueblos pesqueros para la investigación porque el artista investigador identificó una triangulación que ellos crean de manera intuitiva en la playa a partir de tres puntos fijos; es decir, usan la geometría y luego en su 
lancha aplican las matemáticas sin saberlo. Lo más asombroso que identificamos es que la lancha es un cuerpo que se desplaza en un plano en movimiento, lo que significa que ellos ubican tres puntos o marcas fijas en la playa, creando unas coordenadas en su memoria con el fin de desplazarse «a mar abierto» en un plano en movimiento.

Por consiguiente, debo sostener que el objetivo general de la tesis de investigación doctoral de donde deriva este artículo es:

revelar la relación existente entre el patrimonio ideológico de las historias orales y los dibujos mentales de los pescadores de la Boquilla, Taganga y Old Providence y su articulación con los portulanos de la época de la colonia en el contexto del Caribe colombiano (Leotteau, 2018). Dicho objetivo nos permite entrar al universo de estudio con el fin de ejecutar el trabajo de campo etnográfico. Antes de ingresar al campo de estudio, diseñamos una serie de preguntas, una agenda de pesca y de visitas a cada uno de los pueblos pesqueros mencionados anteriormente, por supuesto, en común acuerdo con los pescadores. En este sentido, convivimos mucho tiempo con los pescadores, con el propósito de conocer y aprehender cómo ellos crean sus procesos en la pesca artesanal, sus herramientas y sus mapas mentales.

Al diseñar un listado de preguntas (las que fueron aplicadas para la recolección de información y complementadas con imágenes fijas y en movimiento), pude percibir las emociones y los sentimientos de los pescadores, lo que me permitió cumplir los objetivos específicos de la investigación doctoral, los cuales describimos de la siguiente manera: a) comprobar la relación existente entre los dibujos mentales y las historias orales de los pescadores del Caribe colombiano para ubicar una buena pesca en el Caribbean Sea; b) obtener una reinscripción sobre los dibujos patrimoniales de los portulanos (cartas de navegación), relacionados con el mar Caribe en la época de la colonia; c) legitimar la imagen como herramienta narrativa visual a través del dibujo digital en el contexto del Caribe; d) contribuir a una futura implementación de narrativas hipermediales a un museo interactivo.

Los resultados de esta investigación permitieron que se cumplieran los objetivos apoyados en la metodología etnográfica desde la imagen, por lo que las preguntas aplicadas en las entrevistas contribuyeron a la extracción de las imágenes en la memoria de los pescadores, así como al análisis y la recreación de nuevas imágenes. Asimismo, la información extraída y analizada logró crear un alfabeto visual de imágenes, a fin de hacer una exégesis de las mismas para visualizar los mapas de navegación guardados en la memoria de los pescadores. Del mismo modo, las imágenes orales permitieron identificar algunos sentimientos, emociones, momentos y espacios sobre el contexto, produciendo conexiones entre palabras, gestos y fantasías, que ellos confundían muchas veces con su realidad. El artista investigador, de tanto escuchar historias orales, creó una historia corta («El último Monokarí»), producto de las conversaciones constantes con los pescadores y de su gran imaginación.

Ahora bien, el procedimiento de la extracción de las imágenes de la mente de los pescadores artesanales, a partir de sus relatos y dibujos, generó un nuevo conocimiento con respecto a la aplicación de la metodología de la imagen etnográfica sobre el «patrimonio 
ideológico», dado que se genera la captura, la esencia del mundo simbólico en ese contexto. Estas imágenes revelan sus experiencias por medio de sus historias orales, narradas en las reuniones con sus amigos los fines de semana alrededor de una cerveza. En este sentido, el objetivo de revelar este conocimiento oral a través del dibujo sobre papel es el de comprender esas culturas en sus prácticas identitarias culturales y reconocer su «patrimonio ideológico» en su contexto, introduciéndonos en su mundo y en su «conocimiento empírico».

A algunas imágenes extraídas de la memoria de los pescadores artesanales se les hizo una interpretación sobre el mundo marino, sus sueños y la manera como los pescadores crean sus marcas y algunas formas de desplazamiento para sus rutas de navegación. Una selección de esos dibujos mentales fue llevada a una plataforma digital. Las imágenes aquí descritas hacen parte de los resultados de más de 1500 imágenes recreadas y verificadas por el artista investigador con los mismos pescadores durante la investigación.

Por lo anterior, se abordará la manera como se captura la imagen de la mente de los pescadores con el fin de hacerla visible a ellos y a la comunidad, cumpliendo los pasos desde las entrevistas, la descripción de las imágenes en el contexto de los pueblos pesqueros y de los propios pescadores. Asimismo, el análisis de las imágenes y la recreación y traslados de las imágenes a una plataforma digital.

\section{Métodos y herramientas para capturar imágenes}

Al entrar al campo de estudio para la recolección de imágenes en los pueblos de Old Providence, La Boquilla y Taganga, se identificó primero la población de pescadores artesanales veteranos. A la semana siguiente, se les llevó una carta solicitando el permiso y respetando el derecho de autor para la recolección de imágenes, y se socializó el proyecto de investigación. Con ellos, se planificó una agenda de visitas. El propósito fue identificar los procesos de creación de las rutas mentales. En esas visitas participaron dos miembros del grupo de producción audiovisual VIDENS, acompañando al artista investigador durante varios fines de semana. En cada visita se llevaba el equipo de producción audiovisual, la cámara de video, la grabadora de audio, el cuaderno de apuntes y la cámara fotográfica, disponiendo de tiempo y sobre todo de paciencia para cumplir con las entrevistas y con los objetivos trazados.

En la segunda visita se programó una pesca con un presupuesto asignado; esto, con el fin de comprender la experiencia de la pesca, sus actividades sociales y culturales, así como la relación con el medio ambiente. En términos generales, una de las características comunes en los tres pueblos fue su estrato social bajo y, a veces, muy bajo. Se encontraron muchos problemas ambientales, sociales y económicos, expresados por los mismos habitantes los fines de semanas en la tienda de la esquina al compás de música y cerveza. Con este propósito se ejecutaron las técnicas de las entrevistas en la investigación, fundamentadas en la conversación, tomando cerveza y comiendo sancocho. De este modo logramos ganarnos la confianza de ellos hasta el punto de que nos invitaron a compartir con sus familias y nos hicimos muy amigos. 
Por su parte, para cumplir con la agenda de visitas contamos con el apoyo de la Universidad de Caldas, donde hice mis estudios de doctorado, y la Universidad del Atlántico, apoyado por la Vicerrectoría de Investigación. Estas instituciones me respaldaron con sus cartas, en las que se solicitaba autorización a los líderes de la comunidad de pescadores para la recolección de imágenes y de datos, conversando su derecho, autoría y respeto sobre el registro de imágenes. En común acuerdo, ellos presentaron sus nombres y contaron sus historias orales. Estas acciones se fundamentan en OIT (Oficina Internacional del Trabajo Ginebra), que sostiene:

el respeto a las culturas y las formas de vida de los pueblos indígenas y reconoce sus derechos sobre las tierras y los recursos naturales, así como el derecho a decidir sus propias prioridades en lo que atañe al proceso de desarrollo (OIT, Oficina Internacional del Trabajo Ginebra, 2013).

Esto, dado que los pueblos donde se desarrolló el estudio se encuentran entre los grupos vulnerables en la OIT para la promoción de la justicia social, los derechos humanos y laborales reconocidos a nivel internacional y el trabajo decente. De acuerdo con lo anterior, se procedió a la ejecución de la agenda de visita.

Para entrar en confianza, iniciamos conversando con ellos, sin cámaras, sobre sus experiencias y sobre sus hazas extraordinarias de pesca. Esto motivó el proceso de extracción de los dibujos mentales de la memoria de los pescadores. Al socializarles el proyecto, se les explicó a los pescadores de qué se trataba la investigación y se respondieron algunas preguntas que ellos hicieron. También se les explicó el objetivo de la investigación y cómo se usaría la información. Luego, en común acuerdo, planificamos una pesca, grabando el proceso en audio e imágenes (fotos y videos). Desde la creación de la pesca, se hicieron bocetos previos con el fin de evidenciar y revelar lo que buscábamos en la investigación. Después, se procedió a cumplir con las entrevistas individuales.

Cuando estábamos en el campo de estudio comprendí que la imagen que trasmitían los pescadores era diferente a la que estaba guardada en la memoria de ellos, por lo que eso me llevó a profundizar en el sentido de la imagen desde su metodología. De la información recolectada resultaron las siguientes imágenes: 1) la explicación inicial de una pesca por parte de los pescadores como boceto inicial; 2) el registro de la imagen que identifica a cada uno de los pescadores y su contexto; 3) la narración oral de una experiencia de pesca por parte de los pescadores; 4) el análisis de emociones y sentimientos de los pescadores contando sus historias de pesca en videos y fotografías; 5) un boceto a lápiz para que los pescadores lo identifiquen y verifiquen esas imágenes. Este proceso fue interesante porque describe la manera como los pescadores organizan su carta de navegación a partir de su conocimiento empírico. Con esta imagen consecutiva y con el análisis desde la fenomenología de la percepción, al comprender cómo se perciben las imágenes en nuestro cerebro y cómo estás se visualizan, continuamos con el análisis de las imágenes.

Después de hacer el análisis de las imágenes, se seleccionaron varias de ellas, a las que se les aplicó photo-elicitation. Tanto el proceso como el resultado de las imágenes fue compartido con los pescadores, buscando que fueran ellos quienes identificaran sus propias imágenes. En ese momento, ellos se identificaban fácilmente con lo que habían dicho en las 
entrevistas y se reían de ellos mismos, reflejando sus emociones y sentimientos. Este hecho motivó a hacer una exégesis de las imágenes para su mejor comprensión y visualización de los mapas mentales que los pescadores crean.

Durante todo el trabajo de campo se recolectaron casi 3500 fotografías y alrededor de 50 horas de video. Esta información fue la que permitió comprender las faenas de la pesca artesanal. Cuando se hizo el análisis de la investigación, se identificaron varios elementos antropológicos y culturales: las prácticas identitarias culturales, sus comportamientos sociales, el sentido de la mamadera de gallo, la fenomenología de la percepción, el pensamiento visual, el sentido semiótico de la imagen visual, el lenguaje no verbal, los gestos y las emociones, la autopoiesis, la teoría de la imagen digital; todo ello relacionando con la imagen etnográfica, fortaleciendo metodológicamente la investigación.

Uno de esos aspectos reconocido es el conocimiento empírico de los pescadores artesanales, identificado como <<aquel que se adquiere con la experiencia. Este conocimiento plantea que todas las características que estructuran el pensamiento están dadas por los elementos que el paso del tiempo y de las situaciones vividas van aportando» (Wartofsky, 2016, págs. 412-417), el cual les ayuda a desarrollar un «sentido cognitivo» sobre lo que ellos ven en las profundidades y en la superficie del mar, de acuerdo al color del mar, las corrientes marinas, los vientos y la posición del sol. Este aprendizaje enriquece su conocimiento empírico en la creación de marcas para desplazarse a través de rutas de navegación.

En cada uno de los pueblos de Taganga, La Boquilla y Old Providence se encontró que los pescadores artesanales se apoyan en diferentes tipos de herramientas artesanales e, incluso, en su memoria, la cual utilizan como un recurso importante para sus faenas de pesca a mar abierto.

En primera instancia, definiremos el concepto «señal» como una marca, un signo, un gesto o aviso de algo. La señal es una convención de fácil interpretación. Los pescadores identifican símbolos o marcas en lugares visibles con colores y formas. El Diccionario de la lengua española define «señal» así: «Del lat. mediev. signale 'signo', 'señal', y este del lat. tardío signālis 'que sirve de signo o señal'. Rasgo o nota que se pone o hay en las cosas para darlas a conocer y distinguirlas de otras» (RAE., 2014). Los pilotos de las lanchas identifican y se apoderan de las señales para hacer sus dibujos mentales.

De igual manera, el «punto» se entiende como:

uno de los entes fundamentales de la geometría, junto con la recta y el plano, pues son considerados conceptos primarios, es decir, que sólo es posible describirlos en relación con otros elementos similares o parecidos. Se suelen describir apoyándose en los postulados característicos, que determinan las relaciones entre los entes geométricos fundamentales. El punto es la unidad más simple, irreductiblemente mínima, de la comunicación visual (Weisstein, 1995). 
Los pescadores identifican un «punto» fijo en la playa que ellos puedan ver a la distancia, con el fin de trazar una línea imaginaria a otros puntos (como coordenadas imaginarias) para crear su carta de navegación mental.

En ese orden de ideas, la marca o punto es una referencia fija en la playa a orillas del mar Caribe que, al ser integrada al conocimiento de las corrientes marinas y la dirección de los vientos, ha sido la manera como los pescadores han aprendido a desplazarse en sus lanchas en un plano en movimiento por el mar Caribe.

Como resultado de escuchar y repetir las historias orales sobre la pesca y el conocimiento sobre el mar, los pescadores artesanales de los pueblos de la Boquilla, Taganga y Old Providence tienen su propia manera de percibir las imágenes en su contexto. Los pescadores reconocen que, desde su niñez, sus tíos, sus abuelos y hasta sus padres les han enseñado cómo leer los signos de la naturaleza y el respeto por el mar, dándole significado al conocimiento empírico del mundo de las imágenes que tienen en su memoria.

Cuando los pescadores comienzan a organizar una pesca lo primero que hacen es identificar los signos naturales, asignándole una valoración; es decir, un indicio, como una buena señal, lo que se podría denominar «sabiduría popular o sentido común» (Gómez Alzate, 2018, págs. 429-433). Este último es definido por Zambrano (1995, págs. 429-433) como «la facultad para orientarse en la vida práctica»; es por ello que la sabiduría popular en los pueblos pesqueros, al buscar el mejor lugar para pescar, se relaciona con los deseos y las experiencias de vida, creando ciertas dudas o incertidumbre y fortaleciendo los imaginarios.

Revalorando aspectos que me permiten reconstruir el pensamiento espontaneo de los pescadores, recurro a la manera de pensar con elementos visuales que le permiten al líder de la lancha acoplarse para mantener el liderazgo, jugando con su imaginación. Algunas veces, los pescadores trasladan su mente a las profundidades del mar, recordando sus experiencias. En este sentido, Gastón Bachelard, en su libro La poética del espacio, sostiene que:

La conciencia poética está tan totalmente absorta por la imagen que aparece sobre el lenguaje, por encima del lenguaje habitual — habla, con la imagen poética, un lenguaje tan nuevo- , que ya no se pueden considerar con provecho las relaciones entre el pasado y el presente (Bachelard, 2000, pág. 124).

Aquí observamos claramente cómo los pescadores artesanales, por tener la experiencia de snorkeling, mantienen en su memoria la imagen del fondo del mar y hablan con su propio lenguaje, explicándola como si estuvieran allí y apoyándose también en sus manos para explicar sus sentimientos y emociones por querer vivir en ese mundo marino. El sentido de la luz en la refracción dentro del agua nos da una nueva experiencia que no se puede borrar de nuestra memoria y que algunas veces nos lleva a generar fantasías producidas en el contexto del mar Caribe. Esta es la razón por la cual muchas veces en el mar Caribe se confunde la realidad con la fantasía. 


\section{Una buena pesca}

Una de las preguntas frecuentes que se les hizo a los pescadores durante la recolección de la información fue: ¿cómo se imaginan los pescadores una buena pesca? Es interesante ver cómo los pescadores, en términos generales, sueñan con traer a la orilla el producido de una excelente pesca del día, con el que puedan alimentar a la familia durante una semana y les quede para vender, pudiendo así dedicarse a otra labor durante el resto del tiempo. Sin embargo, los pescadores crean sus propias fantasías, apoyadas en las experiencias de pescas anteriores, generando actividades oníricas reveladas al momento de divulgar sus historias a sus «compas de lucha» (sus amigos). Cabe mencionar que la buena pesca, que extraen del mar, así como sus diversos componentes alimenticios, les provee una serie de proteínas que contribuyen al fortalecimiento de la imaginación de todos en la comunidad.

De igual forma, el hecho de estar sentados durante la faena de la pesca, con el movimiento constante del mar Caribe, la dirección del viento y los colores del mar, les permite recrear sus imaginarios, agregándoles algunos ingredientes de humor, narrando sus propias aventuras y riéndose de ellas. Este tipo de narraciones les ayudan a que la pesca sea mucho más placentera; es ahí donde se crean las historias orales fantásticas que, por sus experiencias, son enriquecidas cada vez más cuando las cuentan. Dichas historias orales son contadas a sus amigos los fines de semana.

Ahora bien, se han encontrado muchas similitudes y divergencias en la manera en la que ejecutan el trabajo colaborativo en los tres pueblos pesqueros. Es muy probable que lo que describen sobre los procesos para desarrollar una buena pesca se les quede grabado en el cerebro, por lo que se apoyan en la experiencia de pescas anteriores, llevándolas a otra experiencia hasta el punto de mezclar la realidad con la fantasía.

Asimismo, existen muchos aspectos que contribuyen a la creación de esas historias orales, las cuales se convierten en ejes centrales de «estrategias de supervivencia» para sus familias: el contexto, la alimentación, las narraciones orales, sus propias historias que viven y recrean. Sin embargo, a veces escuchan otras narraciones orales que son agregadas a las suyas para darles más sentido y jugar con las palabras. Por esta razón, cuando ellos se encuentran tomando cerveza los fines de semana estas historias cobran mucha importancia en el imaginario colectivo a partir del «conocimiento empírico», pues se van retroalimentando, convertidas en historias orales que llegan a hacer tradicionales.

Observamos, entonces, cómo algunos de los nutrientes más saludables que se consumen en los pueblos donde se desarrolla la investigación son los ácidos grasos que contienen algunos peces del mar (identificado como Omega 3 y 6), los cuales benefician al organismo y regulan los niveles de colesterol. En los pueblos donde se desarrolla la investigación, los niños crecen consumiendo Omega 3 y 6, que les da gran fortaleza física y mental, permitiéndoles jugar a ser grandes pescadores como sus familiares más cercanos, porque esto es lo que les enseñan desde pequeños para que busquen el sostenimiento de la familia. $\mathrm{Si}$ bien un buen pescador fortalece sus ideas desde niño, retroalimentándolas hasta convertirlas en historias orales, cuando crece les agrega otros elementos para convertirlas en narrativas esenciales que se transmiten por generaciones. 
Entonces, es posible decir que todo pescador artesanal siempre tiene el sueño de capturar el pez más grande y bonito que exista; esta es una meta que los pescadores se proponen y comentan en sus reuniones. Sin embargo, cuando los pescadores cuentan sus historias orales parece como si hubieran leído la novela El viejo y el mar (Hemingway, 1989), en donde se establece «la lucha del hombre con la naturaleza», similar a sus prácticas tradicionales, creando historias orales a partir de sus vivencias en el mar y de las vivencias escuchadas de sus abuelos, tíos y padres.

\section{Mapas mentales, tinta y lápiz sobre papel}

Cada pescador dibuja en la memoria su mejor pesca bajo las condiciones que él mismo se impone; es decir, él tiene unas metas que cumplir por el bien de su familia. De hecho, el valor más preciado es la familia y, a partir de ahí, nacen las mejores pescas.

\section{Imagen 1. Sea \& waves}

Esta imagen es un dibujo mental extraído por el artista investigador sobre la historia del pescador Amilcar cuando se encontraban en un bote y estaban muy retirados de la playa, Amilcar no veía la orilla, ni los marcadores que habían dejado en la playa, entonces dice él: "maretas y cielo, ahora sí nos perdimos", y los otros compañeros de pesca comenzaron a reírse. Esta expresión está escrita en lengua Kewita de manera horizontal y vertical. Esta lengua es producto de los resultados de investigación. Las líneas rectas describen los trazados y coordenadas que ellos crean, los puntos hacen referencia a los marcadores, las estrellas, las líneas en movimiento describen las corrientes marinas y los vientos, además los ojos que para ellos es muy importante, es la presencia de Dios que los guía y guarda.

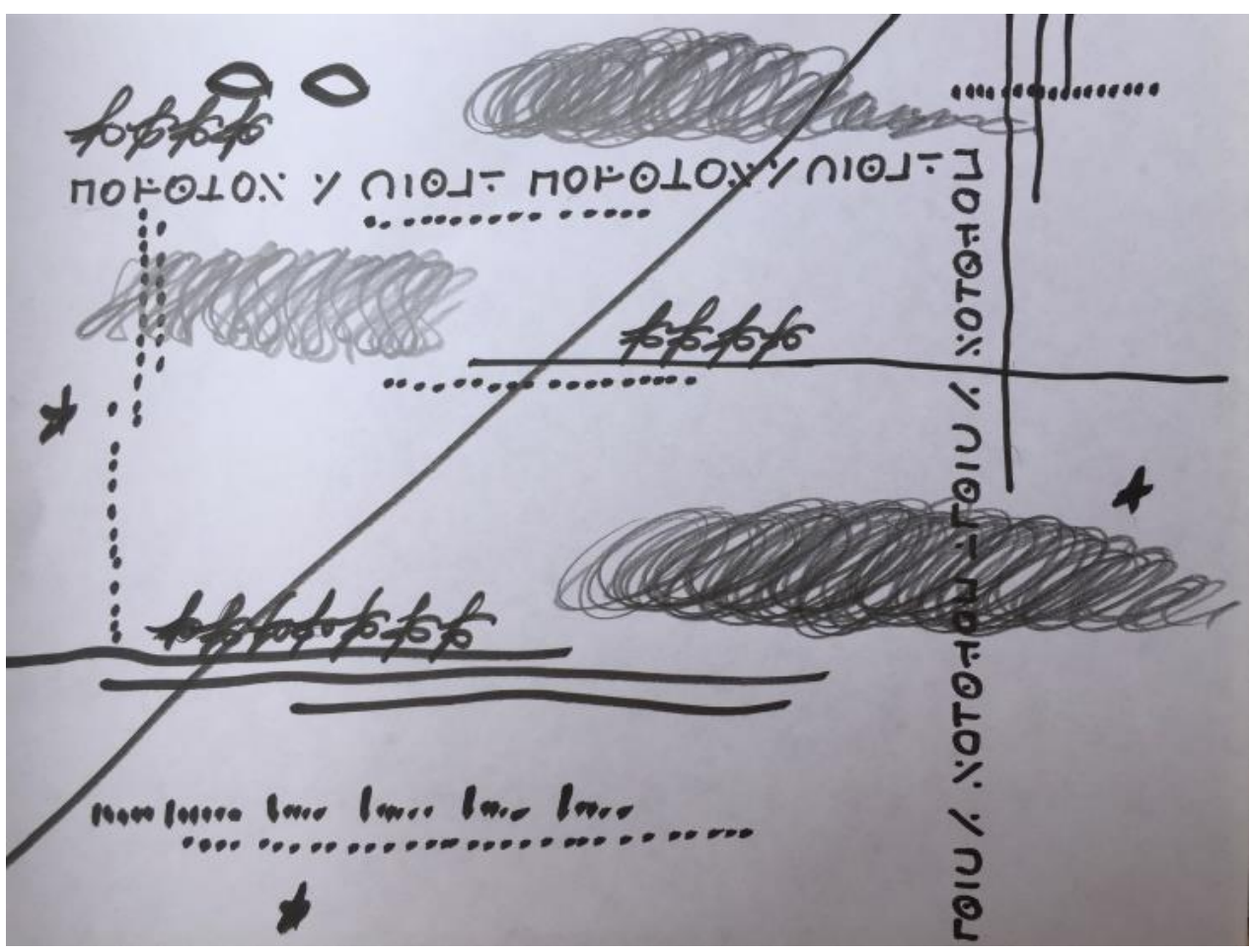

Imagen $\mathrm{N}^{\circ}$ 1. Dibujo $\mathrm{N}^{\circ}$ 103. Autor: Fabian Leotteau. Técnica: Grafito y tinta sobre papel. Dimensiones: $21,59 \mathrm{~cm}$ x 27,94 cm. 
Cabe sostener que los pescadores hacen comparaciones entre sus actividades de pesca, tratando de mejorar cada vez más y llevándonos con sus experiencias al mar Caribe como ninguna otra persona lo puede hacer. Gracias a su experiencia, identifican colores tanto en las profundidades como en la superficie; esto se debe al hecho de haber nacido en ese contexto, en donde todos los días ven el mar y aprenden a diferenciar sus estados. Por lo anterior, Amilcar Avendaño, pescador de Taganga (Pescador artista, 2016), sostiene con emoción y sentimiento que «el mar les provee todo lo que ellos necesitan, de donde puedan sacar un beneficio económico para el bien de la familia».

En la imagen $\mathrm{N}^{\circ} 1$ se puede ver cómo el pescador describe el mar y las olas en su mente. Esta imagen es extraída por el artista investigador de la mente de Amilcar. En ella, el pescador comienza a construir sus historias. Este dibujo muestra los puntos fijos que los pescadores crean en la playa para su desplazamiento por el mar; podemos decir que este es un mapa mental. De este modo, «el pescador se apoya en el "conocimiento empírico" y en la "sabiduría popular" para crear sus marcas o puntos que utiliza como referencia para navegar sin necesidad de usar GPS» (Leotteau, 2018).

Esta manera de interpretar el mar les permite a los pescadores hacer su sitiogeografía y reconocer las bondades que posee el mar Caribe pues, como menciona Francisco Varela (2000), «la relación existente entre el cuerpo interno con el contexto» hace referencia a las experiencias vividas de los pescadores en su comprensión y el respeto por el mar. Los pescadores reconocen que el mar les provee sus alimentos y ellos también conocen sus profundidades y las motivaciones que les produce para crear sus propias historias orales.

Por su parte, los pescadores artesanales describen el color de las profundidades del mar apoyándose en sus manos, haciendo un dibujo en el aire sobre lo que observan porque ellos practican el esnórquel y tratan de traer a la superficie ese hecho real de lo que ven y lo que sienten en esos momentos. Cuando los pescadores describen sus historias orales con sus propias palabras, se acuerdan y representan la refracción de la luz de una manera particular; sus ojos se iluminan y se llenan de emociones y sentimientos, pareciera que el agua fluyera en esos momentos. En ese sentido, ellos recuerdan los colores de los arrecifes, los colores transparentes de las profundidades del mar que se ven durante el día. Algunos comentan que es como vivir en otro mundo.

\section{Imagen 2. These are lived experiences.}

Esta imagen es un dibujo mental extraído por el artista investigador sobre la historia del pescador SantaPri cuando estaba contando la historia sobre sus experiencias vividas. Esta expresión dice "estas son experiencias vividas" escrita en lengua Kewita de manera horizontal y en el intermedio de la imagen del lado izquierdo dice SantaPri. Las líneas rectas describen los trazados y coordenadas que ellos crean para crear su mapas de navegación, los puntos hacen referencia a los marcadores, las estrellas, las líneas en movimiento describen las corrientes marinas y los vientos, además los ojos que para ellos es muy importante, es la presencia de Dios que los guía y guarda. El círculo en el medio de la imagen con una línea hacia arriba es la representación simbólica del SantaPri y su proyección hacia el mar. 


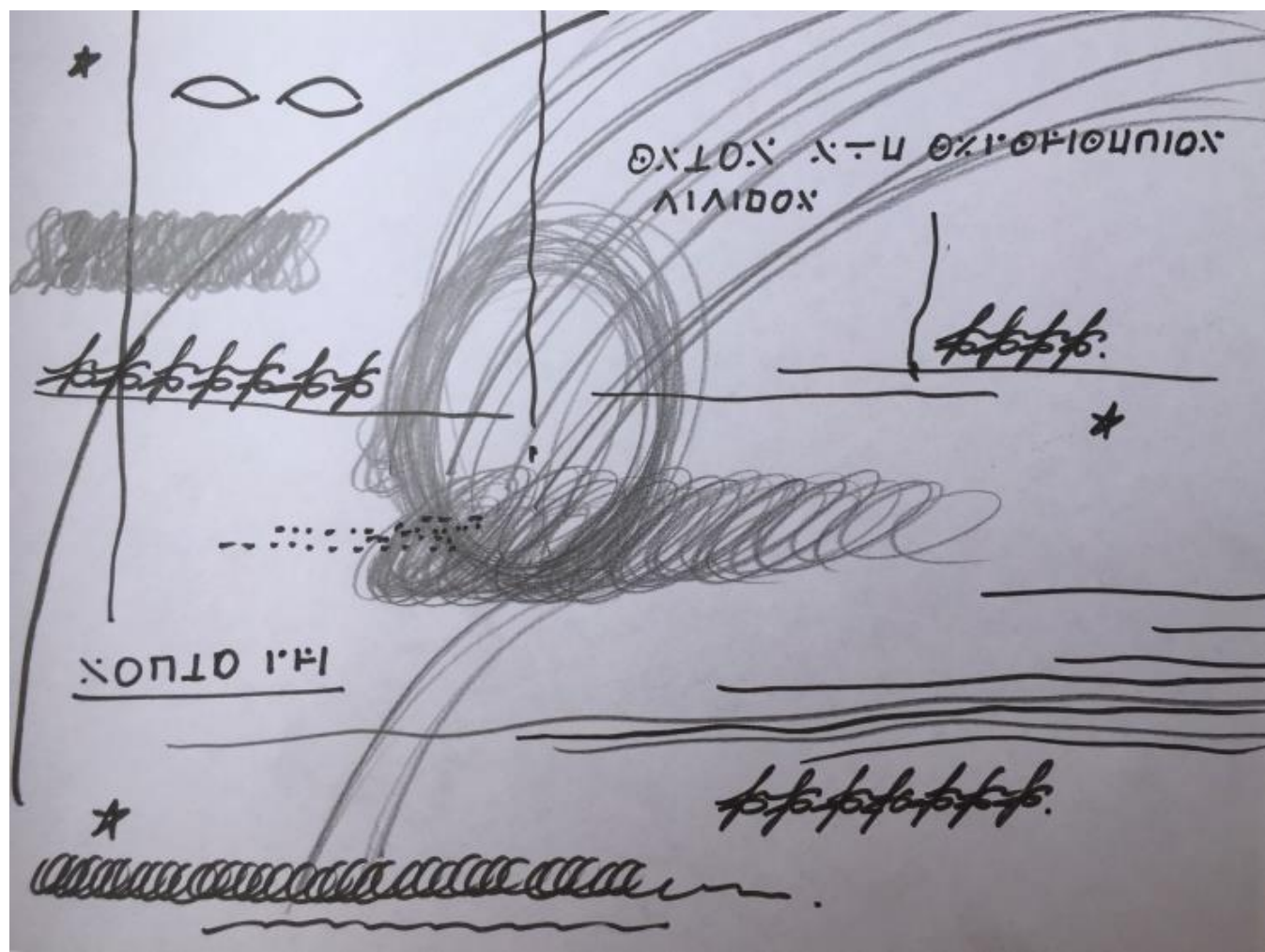

Imagen $\mathrm{N}^{\circ}$ 2. Dibujo $\mathrm{N}^{\circ}$ 124. Autor: Fabian Leotteau.

Técnica: Grafito y tinta sobre papel.

Dimensiones: $21,59 \mathrm{~cm}$ x 27,94 cm.

Para comprender la imagen presente en la mente de los pescadores es necesario que se observen los trazos del lápiz en la imagen $\mathrm{N}^{\circ} 2$, en la que los pensamientos se dirigen en una dirección, como si el pescador buscara dentro de su mente. Esas imágenes, fragmentadas y guardadas en su memoria, son las que reconstruyen su mapa mental. Debemos entender que las imágenes que guardamos en nuestra memoria son fragmentadas; por ello, el pescador recurre a sus hazañas de pescas anteriores para reconstruir sus historias orales. Cada línea sobre el papel describe un movimiento, como si volara y se trasladara a través del mar para ubicar el mejor lugar de la pesca. El pescador proyecta en su memoria una dirección en el mar y la describe con sus manos y su dedo índice para conectar los puntos fijos que se encuentran en la playa. Es decir, construye en su mente y en el espacio un plano cartesiano en movimiento con su mano, extendiendo su memoria hasta el lugar donde irá a pescar.

De acuerdo con lo anterior, se evidencia cómo las imágenes fragmentadas, guardadas en la memoria basada en la fenomenología de la percepción visual, reinventan la realidad con propiedades existentes del mundo de la pesca. Los pescadores artesanales forman una imagen de su realidad con la excusa de que cualquier cosa sirve para inventar una pesca. En este sentido, Francisco Varela (2000) expresa que «nuestro mundo es imaginación y fantasía, y es por esto que es de fundamental importancia que los niños desarrollen el suyo»; asimismo, los pescadores artesanales construyen su mundo desde niños, en los que la imaginación y la fantasía hacen parte del mundo del diario vivir porque en esos lugares 
donde ellos nacen, a orillas del mar Caribe, solo ven la línea del horizonte y siempre desean saber que existe más allá de ella.

\section{Imagen 3. Once I got lost}

Esta imagen es otro dibujo mental extraído por el artista investigador sobre la historia del pescador SantaPri, similar a la imagen 1., la cual hace referencia cuando los pescadores se encontraban en un bote y estaban muy retirados de la playa, no veía la orilla, ni los marcadores que habían dejado en la playa. La expresión dice "una vez me perdí y solo veía cielo y mareta", está escrita en lengua Kewita de manera horizontal. Esta lengua es producto de los resultados de investigación. Las líneas rectas describen los trazados y coordenadas que ellos crean, los puntos hacen referencia a los marcadores, las estrellas, las líneas en movimiento describen las corrientes marinas y los vientos, además los ojos que para ellos es muy importante, es la presencia de Dios que los guía y guarda.

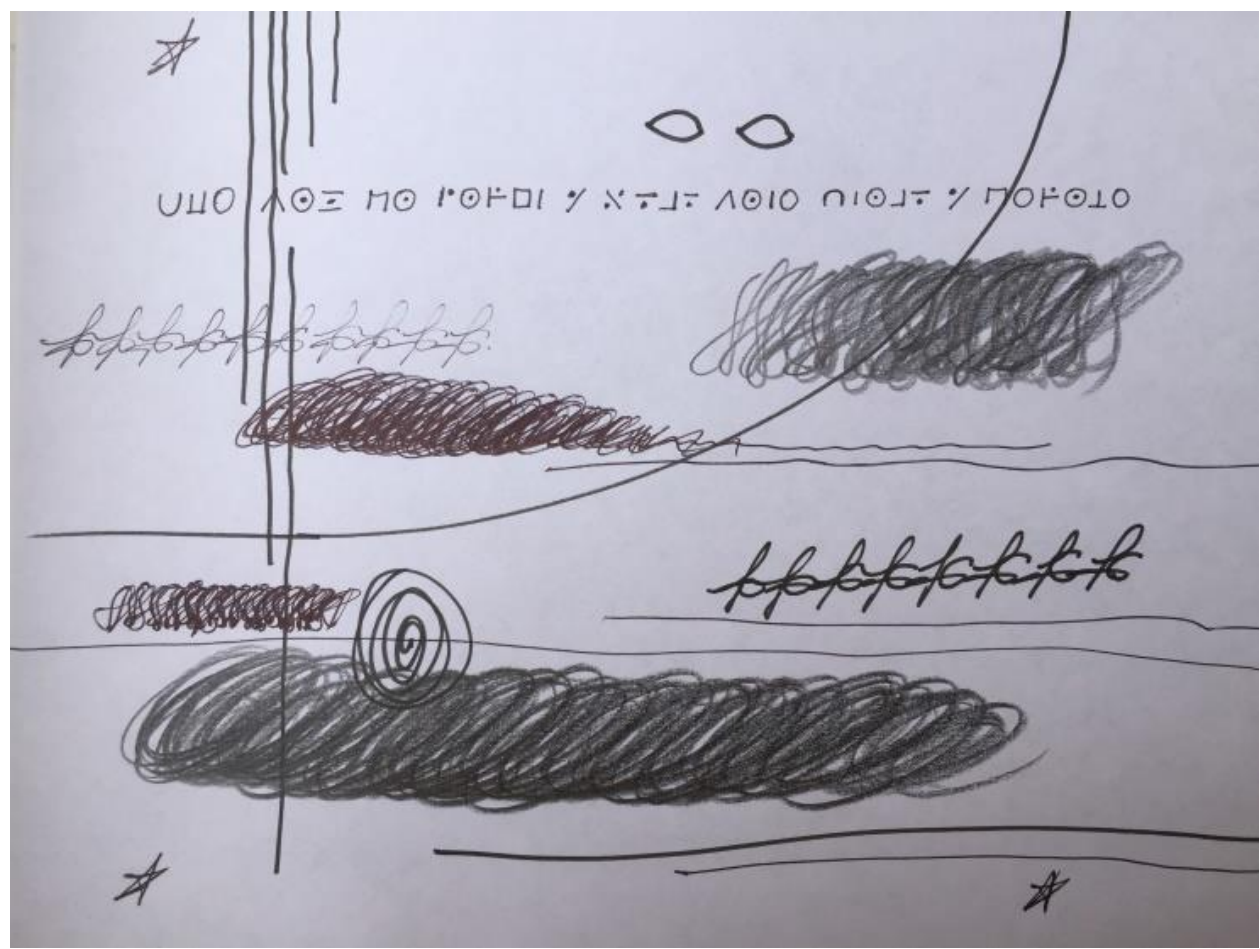

Imagen $\mathrm{N}^{\circ}$ 3. Dibujo $\mathrm{N}^{\circ}$ 125. Autor: Fabian Leotteau.

Técnica: Grafito y tinta sobre papel.

Dimensiones: $21,59 \mathrm{~cm}$ x 27,94 cm.

La imagen $\mathrm{N}^{\circ} 3$ narra la historia oral en la que «El SantaPri», pescador de La Boquilla, se perdió en una ocasión en el mar y duró dos días flotando en la superficie hasta que llegó a una playa y varias personas de un pueblo de pescadores cercano lo ayudaron y lo sacaron. Sus recuerdos son descritos en esta imagen, interpretada con trazos de grafito y tinta: las corrientes marinas, el oleaje y el movimiento en las profundidades del mar.

Con este propósito, los pescadores desarrollan sus actividades memorizadas y las ejecutan organizadamente. Ellos construyen sus historias a partir de esos momentos; es decir, 
cuando identifican cada uno de los signos de la naturaleza. Sin embargo, cuando se desplazan «a mar abierto» cada uno debe estar en su puesto en la lancha para cumplir su función durante la faena; es decir, sacar los peces capturados y evitar que se salgan de la lancha. Este es un trabajo que debe hacerse cuidadosamente porque después de que capturan el pez este puede brincar y salir de la lancha. Esos momentos son muy importantes para ellos porque se divierten cuando se le escapa un pez a uno de los «compa de lucha», como dicen en La Boquilla, y se burlan del compañero durante un tiempo.

Otro componente que contribuye a la creación de marcas o puntos es el desarrollo de un trabajo colaborativo. El trabajo colaborativo es importante desde la preparación de la embarcación. Ellos verifican cada uno de los elementos que deberían llevar y si están en la lancha, haciendo que la responsabilidad individual se vaya consolidando en la colectividad durante las distintas etapas de la pesca.

\section{Imagen 4. Fight with a shark}

Esta imagen es la historia del SantaPri cuando cuenta que tuvo una lucha con un tiburón. Es fascinante oírlo contar esa historia porque le pone emociones y sentimientos con gestos y sus manos. Esta expresión está escrita en lengua Kewita de manera horizontal y se repite 3 veces, porque él le encanta repetirla. Las líneas rectas describen los trazados y coordenadas que ellos crean, los puntos hacen referencia a los marcadores, las estrellas, las líneas en movimiento describen las corrientes marinas y los vientos, además los ojos que para ellos es muy importante, es la presencia de Dios que los guía y guarda.

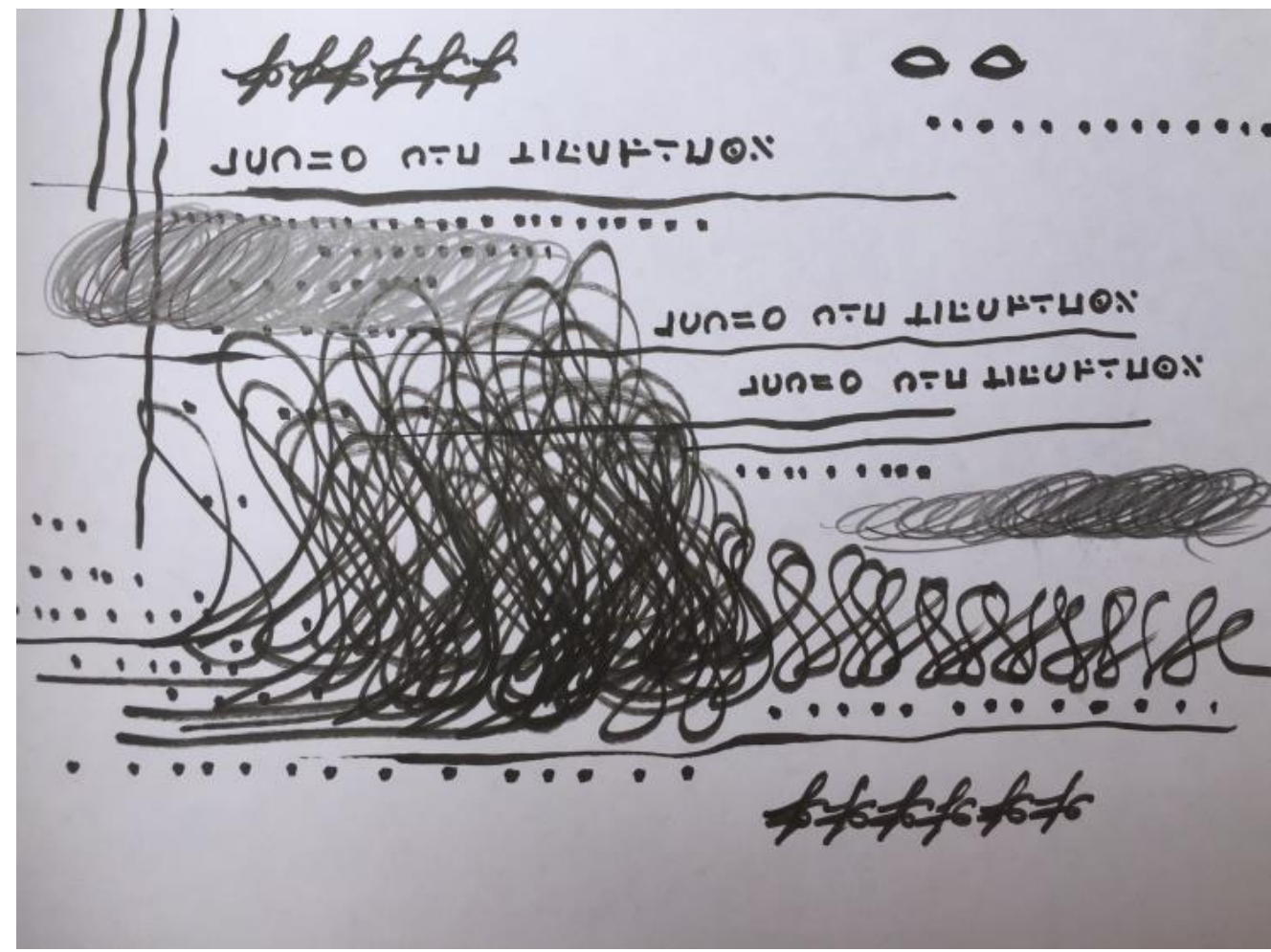

Imagen $\mathrm{N}^{\circ}$ 4. Dibujo $\mathrm{N}^{\circ}$ 126. Autor: Fabian Leotteau.

Técnica: Grafito y tinta sobre papel

Dimensiones: $21,59 \mathrm{~cm}$ x 27,94 cm. 
La imagen $\mathrm{N}^{\circ} 4$ describe «el SantaPri» luchando contra un tiburón. Esta hazaña fue contada por «el SantaPri», como si hubiera leído El viejo y el mar (Hemingway, 1989). El imaginario y la imaginación del «SantaPri» constituyen un factor fundamental para la creación de sus historias orales: su conocimiento empírico articulado a las imágenes imborrables en su piel y su memoria hacen que sus historias tengan una nueva versión cada vez que las cuenta.

Cabe mencionar que el análisis de las imágenes en sus distintas fases generó una serie de interpretaciones, las cuales abrieron otra puerta hacia la imagen etnográfica, buscando abordar la extracción en sus procesos y procedimientos; es decir, cómo esa imagen puede llegar a ser visualizada mediante un soporte fluido.

La imagen en la memoria de los pescadores funciona para ellos. Sin embargo, solo después de recibir las distintas imágenes (la oral, la gestual, la visual, la táctil, y hasta la olfativa y descriptiva) de parte de los pescadores, fue posible reconstruir esas imágenes fragmentadas en un soporte de papel para que el resultado fuera verificado por ellos mismos. Por este motivo, surge una pregunta: ¿cómo se podría llevar esa imagen que se encuentra en un soporte de papel a una plataforma digital, cumpliendo y respetando el derecho y la autonomía de la creación de marcas de parte de los pescadores artesanales?

\section{Dibujos mentales del SantaPri llevados a una plataforma digital}

Al pasar las imágenes del soporte en papel a la imagen digital (como transferencia de información a un soporte fluido y digital) se produjeron otras imágenes que nos ayudaron a comprender y visualizar la fascinación del mundo de la pesca.

Cuando se pudieron extraer las imágenes de la mente de los pescadores para llevarlas a un soporte rígido (como es el papel) y luego pasarlas a uno digital, esos dibujos, relacionados entre sí, se unían en «la metáfora de comunicación y movimiento» (Hernández Carcía, 2005, pág. 95), fortaleciendo el patrimonio ideológico a partir del conocimiento empírico. De este modo, los pescadores convierten esas acciones en expresiones jocosas en la vida diaria porque ellos se burlan de la vida y de la muerte metafóricamente en sus narraciones. Lo que me llevó a preguntar: ¿cómo, al extraer esa imagen, la puedo procesar desde su captura conservando el movimiento en un soporte fluido para visualizarla? Para responder a esto podemos decir que la necesidad de comunicación entre los miembros de los pueblos ancestrales contribuyó al fortalecimiento de la comunicación en el desarrollo del lenguaje y de la invención de la comunicación y la escritura, creando una serie de signos que todos conocieran a fin de mantener un lenguaje común de comunicación. Ese lenguaje de comunicación generó signos, los que fueron identificados como códigos visuales que, más tarde, conformaron lo que hoy llamamos «alfabeto». Ahora bien, los números comenzaron a complementar las acciones del lenguaje debido a la necesidad de saber contar. Es así como algunos pueblos ancestrales se fundamentaron en códigos visuales, auditivos y, a veces, táctiles, que les permitían comunicarse entre sí y con los demás.

De igual forma, con la información recibida durante la investigación me vi en la necesidad de crear un alfabeto y un lenguaje visual para comprender los mapas mentales de 
navegación y acercarme a ese conocimiento empírico: aquel en el que los pescadores se apoyan en su contexto. No debemos olvidar que en el siglo XVIII se creó en el gran Caribe una nueva lengua, el creole, producto de la mezcla de otras lenguas traídas al mar Caribe; por ello la facilidad de crear imaginarios en otros lenguajes de manera intuitiva en este contexto.

De hecho, el llevar la imagen a otro soporte (en este caso, del soporte en papel al digital) me lleva a la relación de la interfaz humano-máquina en «la interacción interna». Aquí debemos identificar si la interacción es con la máquina o con el ser humano que captura la imagen, porque identificamos tres tipos de imágenes: una, que es la que está en la mente del artista; otra, que captura la máquina, y una más, la de tiempo-espacio. Es decir, al momento de registrar la imagen (ya sea fija o en movimiento) se generan otras imágenes que no estaban relacionadas antes.

Ahora bien, el tipo de imagen que desea capturar el humano también corresponde a la imagen de la información que poseemos en nuestro fluido sanguíneo, ya que no solo es la interacción de la máquina, sino también la imagen que tenemos en nuestro cerebro, la cual se convierte, al extraerla, en otra imagen, pero necesita de un soporte para ser visualizada. Entonces, surge otra pregunta: ¿cómo afecta la información del fluido sanguíneo de nuestro cuerpo en la interfaz con la máquina? El proceso consistió en capturar el dibujo mental desde el cerebro de los pescadores artesanales, mediante la etnografía de la imagen que luego dibujé sobre papel; esa imagen, verificada con las imágenes de los audios y los videos, permitió que surgiera otra imagen, la $\mathrm{N}^{\circ} 4$. De ahí resultó la quinta imagen, para cuya verificación con los pescadores me apoyé en photo-elicitation, fundamentado en Sara Pink (2012). De esa quinta imagen es que pasamos a la imagen digital que es la sexta imagen; sin embargo, se debían organizar las imágenes, encontrando otros problemas que resolver para dar respuestas, en la séptima imagen, en un mar digital.

Ahora bien, la metodología aplicada en la creación de los mapas mentales en la infografía «Dibujos mentales del SantaPri» fue abordada desde dos visiones: una, desde el universo de estudio en su contexto y, la otra, desde la tecnología y la estética digital. Debo aclarar que para introducirme en la creación de la infografía primero reconocí los contenidos y el contexto a fin de complementar la nueva imagen en la virtualidad desde los conceptos en las artes mediales.

En ese orden de ideas, me hice varias preguntas; entre ellas: ¿cómo puedo introducir la imagen en la virtualidad, conservando los principios de los pescadores? Parecía fácil, pero no lo era, pues debíamos respetar la manera intuitiva en como ellos crean sus mapas y sus historias orales para llegar a la sexta y séptima imágenes. Aquí debo mencionar que en la sexta imagen me pregunté: ¿cómo voy a trasladar esa imagen para hacerla visible en una plataforma online?

El resultado de la séptima imagen fue la infografía «Dibujos Mentales del SantaPri», desarrollada en una plataforma online. Esta me ayudó a profundizar sobre el proceso de creación de mapas mentales. La extracción de las imágenes y la exploración de la información en la infografía generó una nueva imagen secuencial en la red de tecnología a partir de la interconexión entre puntos y marcas, apoyada en la estética digital. Esta 
experimentación de creación de mapas mentales en una plataforma digital contribuyó al fortalecimiento de la exploración con recursos digitales en los que se produjo una serie de pasos similares a los que los pescadores desarrollan de manera empírica. La información visual me ayudó en la consecución de la organización de las imágenes en la infografía, en la interfaz y en el ecosistema digital.

La plataforma seleccionada con la que se hizo la infografía fue escogida por la función de producir un movimiento de un punto a otro en la pantalla, similar al trazado que hacen los pescadores artesanales en su memoria. Fue por ello que la plataforma digital contribuyó a ampliar y mover la imagen ubicada en la pantalla.

Imagen 5. Dibujos mentales del SantaPri

Esta imagen es un dibujo digital que describe con líneas rectas los trazados y coordenadas que los pescadores crean, los puntos hacen referencia a los marcadores, las estrellas, están ubicadas sobre una imagen en Old Providence, las cuales se conectan unas con otras.

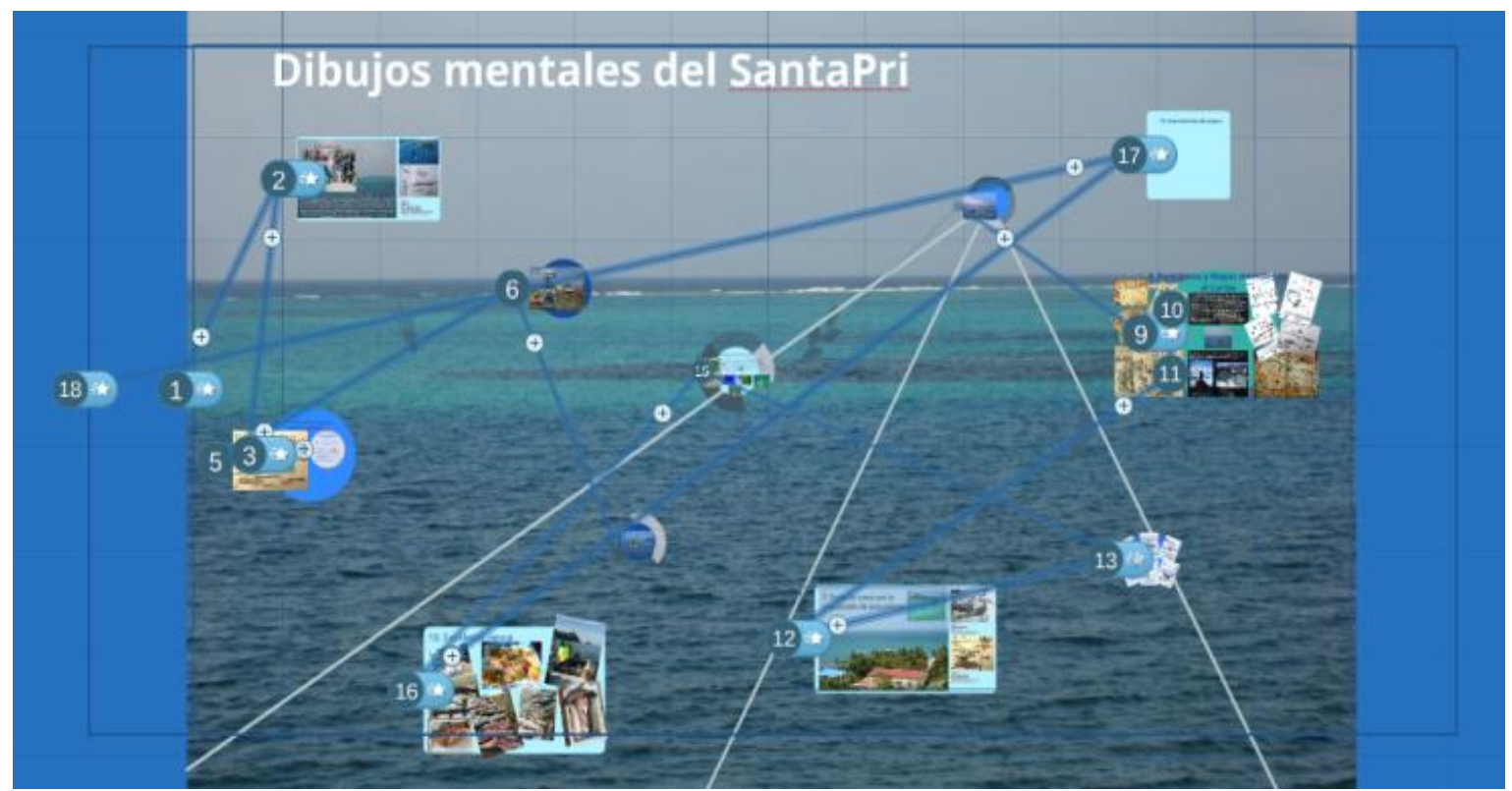

Imagen $\mathrm{N}^{\circ}$ 5. Infografía: Dibujo digital. Autor Fabian Leotteau.

Captura de la imagen por el artista investigador.

Esto significa entonces que la infografía ha sido uno de los aportes desde el diseño y la creación. Al explorar el quinto dibujo para llevarlo a las tecnologías obtenemos como resultado otra imagen, esta vez digital.

De este modo, al experimentar en la plataforma online pude abordar los mapas mentales desde la estética digital porque, aunque los había abordado desde la captura de la imagen, no había tenido en cuenta la creación de la imagen desde la «endoestética» que, según Claudia Giannetti (2018), es:

la estética de la virtualidad (del carácter inmaterial de los elementos constitutivos del mundo virtual), la estética de la interactividad (de la relatividad del observador en relación 
al sistema y la prominencia del interactor en el contexto del sistema), y la interfaz (el sistema mediador entre el mundo artificial y el sujeto). En su conjunto, estos cuatro elementos conforman los principios básicos de la endoestética (p. 96). ". Por lo que, el proceso de creación de la infografía conformada conceptualmente desde la «endoestética» a partir de sus fases anteriores, nos lleva al siguiente paso de trasladar esos dibujos sobre papel a la virtualidad, transformándose en signos codificados que evidencian una imagen. Ahora bien, esos dibujos mentales virtuales se pueden mover igual como los pescadores piensan sobre sus desplazamientos, lo que arrojó como resultado un mundo simulado en un plano en movimiento en el mar Caribe colombiano en una plataforma digital online.

Imagen 6. Proceso de marcar en el mar

Esta imagen describe las fases del proceso cuando los pescadores comienzan a crear la ruta de navegación para salir a pescar.

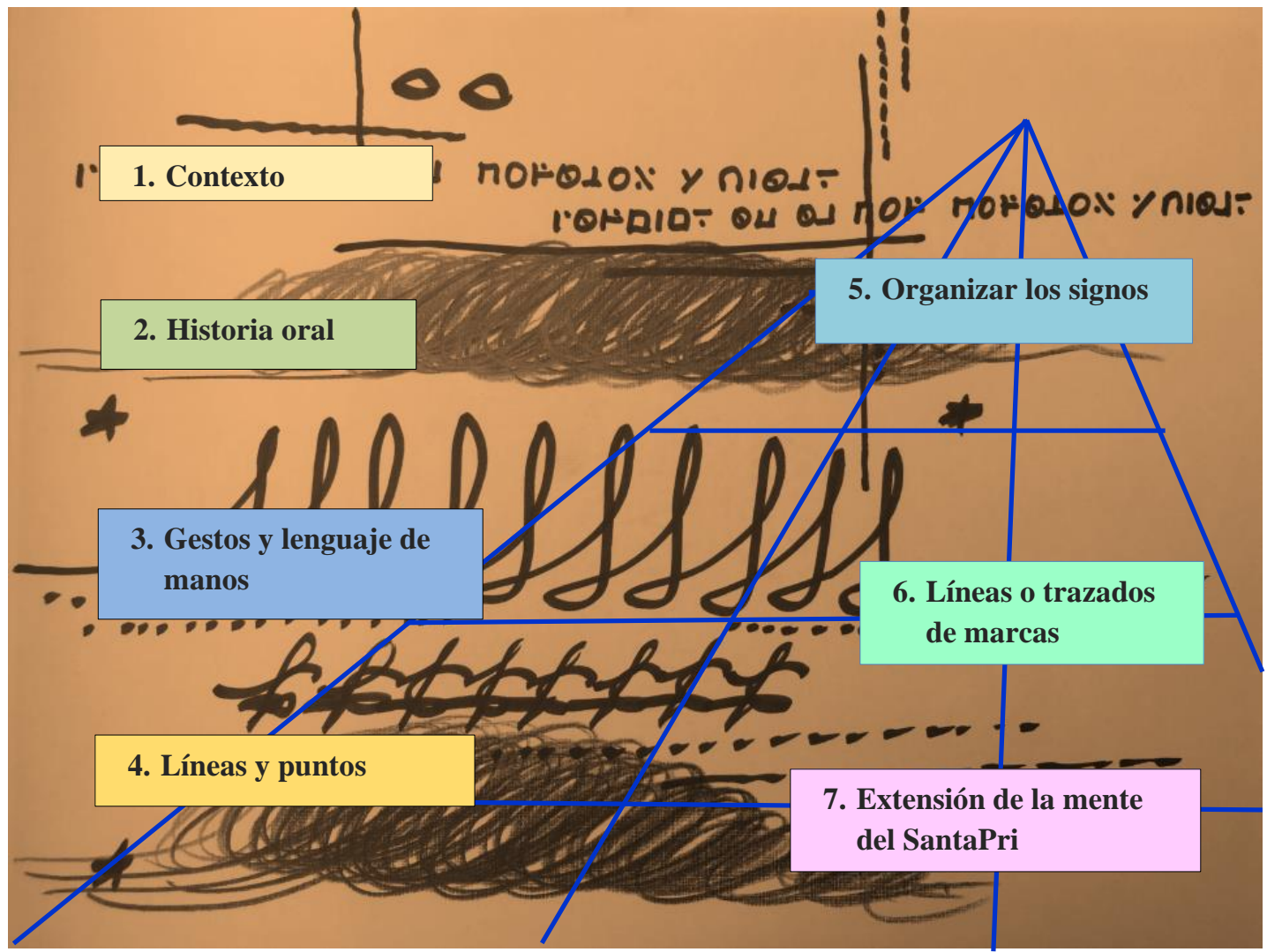

Imagen $\mathrm{N}^{\circ}$ 6. Autor Fabián Leotteau.

Detalle de la Infografía. Dibujo digital. Dibujos mentales del SantaPri.

Imágenes del artista investigador.

De igual manera, la obra «Agua», de Rejane Cantoni y Leonardo Cresenti (Cantoni, 2010), me generó mucho interés al comprender cómo ellos manejan el sentido metafórico del agua en un ambiente simulado de sensaciones, articulado a espejos flexibles muy grandes. Además, el cómo ellos juegan con los materiales y las herramientas tecnológicas articulados al sistema STEAM (Science, Technology, Engineering, Art and Mathematic) en el tiempo-espacio. Esta obra expresa el sentido de un cuerpo que se desplaza en un plano en movimiento en el momento en el que el público interactúa en una conciencia cibernética; es 
decir, como si estuvieran flotando en el mar, sin mojarse. Fue una experiencia que me llevó a comprender y a ver el mar digital desde otro punto de vista: el de la simulación y la fantasía, tal como los pescadores crean sus desplazamientos antes de salir a pescar. De este modo, el propósito de la infografía es darle movimiento a los mapas mentales de los pescadores artesanales del mismo modo que lo hicieron Cantoni y Cresenti, pero en una plataforma digital, sin espejos.

De hecho, «la metáfora de comunicación y movimiento», de Giannetti (2005, pág. 95), sirve al sujeto como forma de comunicación, apropiándose del entorno para transferir y aplicar el conocimiento; esto es lo que los pescadores hacen muchas veces sin saber qué es una «metáfora de comunicación y movimiento». Sin embargo, los pescadores aplican sus propios métodos de organización, como el tejido de una red de pescar: cada uno hace lo suyo para ejecutar sus faenas de pesca, llevándolos a jugar con la «metáfora de comunicación y movimiento».

Consecuente a ello, vamos a la imagen guardada en la memoria de los pescadores identificada como una «imagen de arqueología visual» (Giannetti, 2018, pág. 94). Es con la imagen personal con la que viven los pescadores en su mente con la que expresan y promueven sus motivaciones para salir a pescar, por lo que esa imagen se encuentra en constante diálogo con las imágenes del contexto debido a que viven a orillas del mar. Estas imágenes son construcciones y contenidos enriquecidos con un lenguaje propio de los pescadores; por ello la importancia de una etnografía de la imagen respetando el derecho de las imágenes mentales de los pescadores.

Puedo decir que el media art generó una nueva mirada desde la visión del artistainvestigador, que me lleva a la era digital en las formas de comunicación: abierta, bidireccional y unidimensional, entre el humano y el medio. De este modo, existe un paralelismo entre la creación de la infografía y la creación de los mapas mentales, en cómo los pescadores artesanales crean sus mapas de navegación a partir del «conocimiento empírico», permitiéndonos retroalimentar el «patrimonio ideológico».

Asimismo, la infografía permitió comprender y reconocer lo que los pescadores hacen de manera intuitiva; es decir, la forma en cómo ellos crean esos mapas mentales de forma natural que, en esta oportunidad, nos fue posible visualizar. Recordemos que ellos se apoyan en gestos y palabras y que solo vemos las emociones y los sentimientos cuando narran sus historias.

Entonces, la séptima imagen se fue construyendo a partir de recursos tecnológicos usados durante el trabajo de campo. Después de obtener esos resultados, estos me ayudaron a comprender y a responder una de las preguntas: ¿para qué sirve esa información? La respuesta es: para comprender cómo los pescadores artesanales pueden navegar sin necesidad de usar GPS y, más que eso, para comprender la manera en cómo crean marcas y puntos en su contexto para salir a navegar a mar abierto. La información también contribuye al fortalecimiento del «patrimonio ideológico» en cada uno de los pueblos donde se desarrolla la investigación. Además, al asistir a la exhibición Antillean visions; Maps and the making of the Carriean: An Exhibición of Cartograpihc Art (Miami, 2018), en The Lowe Art Museum, University of Miami, pude experimentar cómo la información 
de un mapa contribuye a la imaginación de los niños, al aprehender sobre las corrientes marinas y los vientos en el mar Caribe, y cómo también los motiva a navegar y a ejecutar una aventura por el mar Caribe: se trató de una experiencia de mucho interés porque encontré esta otra respuesta a la pregunta anterior.

\section{Imagen 7.}

Esta imagen es una de las salidas a pescar con el pescador Amilcar cuando vamos navegando, las líneas rectas describen los trazados y coordenadas que ellos crean, los puntos hacen referencia a los marcadores, se alcanza a ver las corrientes marinas y los vientos.

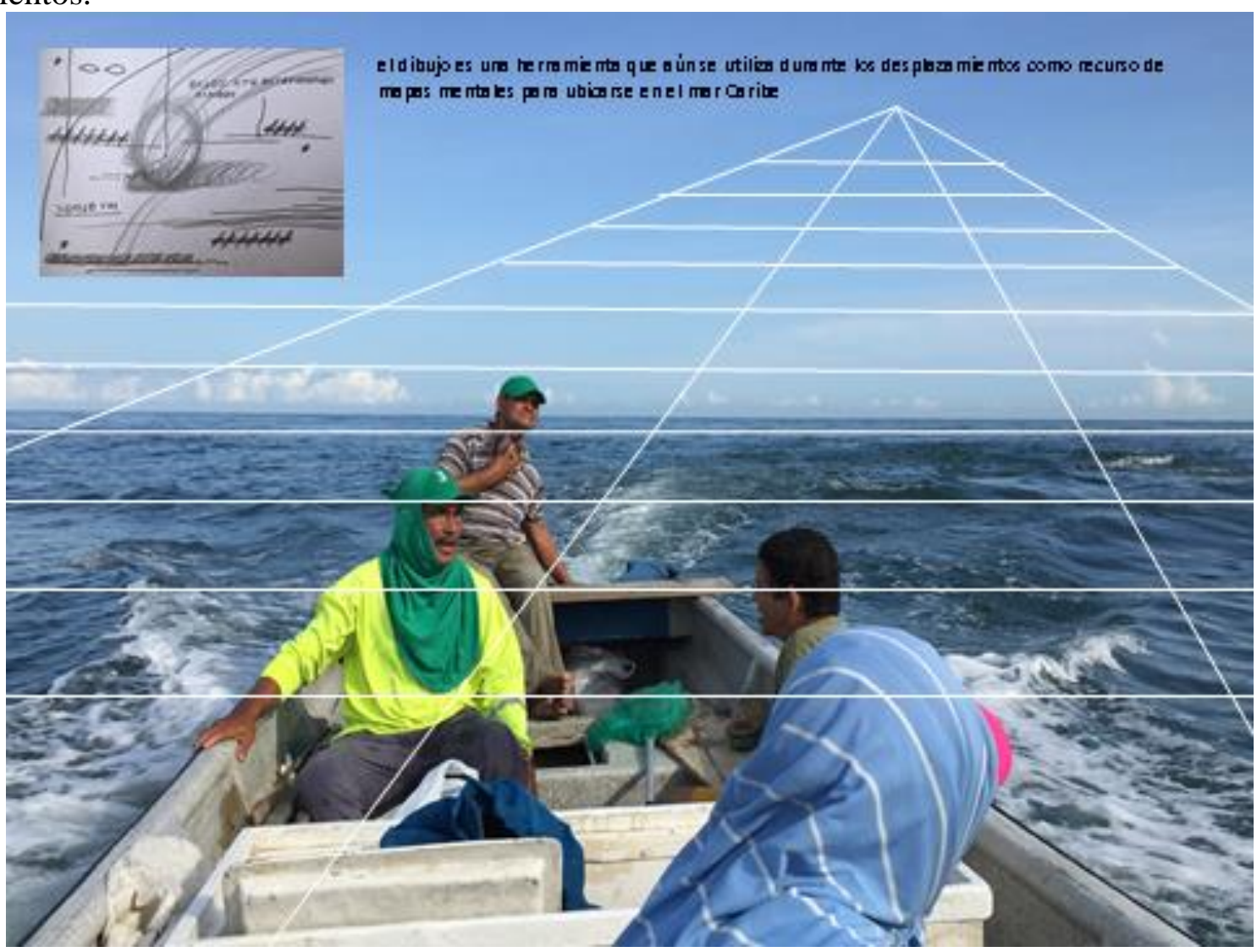

Imagen $\mathrm{N}^{\circ}$ 7. Detalle de la Infografía.

Autor: Fabián Leotteau.

Dibujo digital. Dibujos mentales del SantaPri. Imágenes del artista investigador.

Por ello, la producción de imaginarios visuales llevados a la virtualidad se exploró en la interconexión en la red de tecnología como otro de los resultados de la tesis doctoral. De este modo, al experimentar las imágenes en los nuevos medios, se obtuvo como resultado posibles soluciones en la interfaz por el uso de las nuevas herramientas tecnológicas, nuevas formas de hacer arte, articulando las ciencias básicas aplicadas a la investigación.

Ahora bien, debemos entender que la imagen que vemos en la plataforma online no es real, sino que es lo que produce un código fuente, alfanumérico, que identifica cada uno de los números binarios en el screen; por ese código es que se pudo configurar y mover la imagen 
en la pantalla. De manera similar, los pescadores crean sus códigos visuales artesanales que les funcionan para la creación de sus trazados mentales.

\section{Imagen 8.}

Esta imagen es el código de la fotografía de la imagen 7, en la plataforma prezi. Este es un lenguaje binario que se usa en internet. De igual manera los pescadores veteranos usan unos códigos que muchas veces nosotros no entendemos. Esta es una de las razones por la que cree un lenguaje, para generar una interconexión entre la imagen y el lenguaje binario que no se ve, pero hace que se vea la imagen.

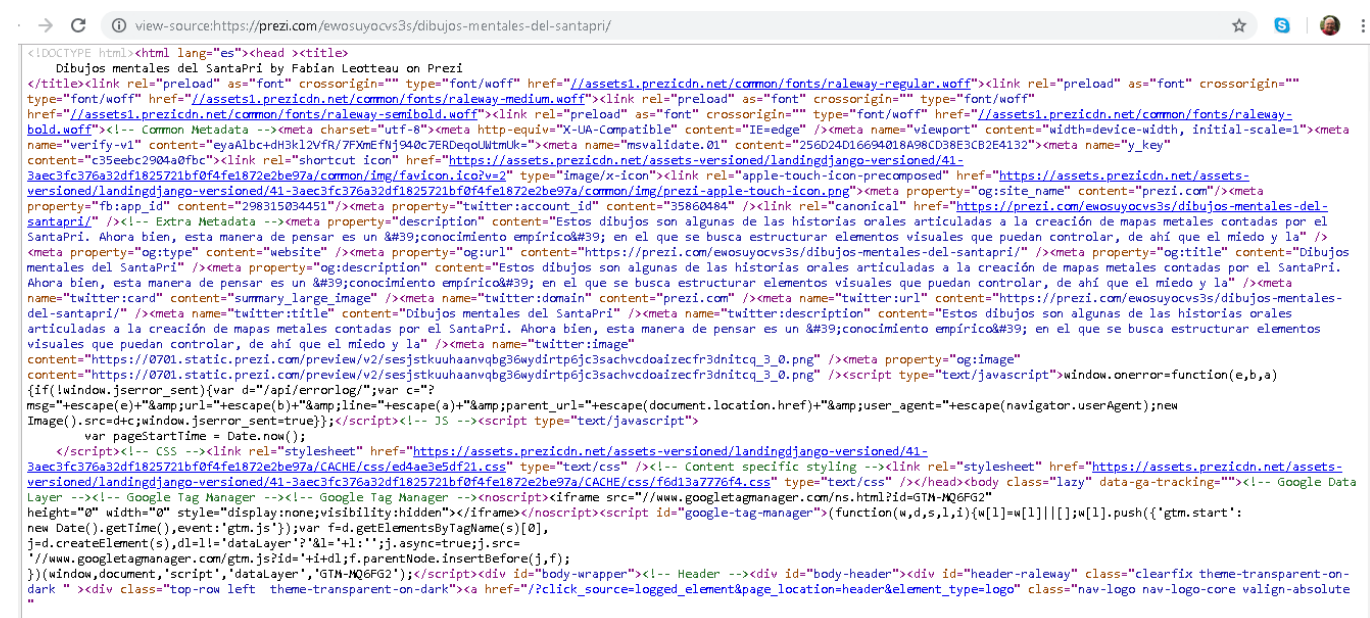

Imagen $\mathrm{N}^{\circ}$ 8. Detalle código fuente view-source:https://prezi.com/ewosuyocvs3s/dibujosmentales-del-santapri/

Captura de imagen por parte del artista investigador.

El código fuente arrojado en la plataforma digital logra un diálogo entre los sistemas virtuales y la expansión del universo cognitivo de los pescadores. Por ello, las condiciones del sistema Prezi me proporcionaron la sensación de interactividad del entorno virtual entre la información de la creación de mapas mentales.

A partir de la autobservación, el sistema Prezi me da la sensación de moverme en el mar del Caribe colombiano como si estuviera navegando en una lancha, como un juego simulado; por ese motivo, la visualización en la edición direccional de las imágenes, con las líneas y puntos encontrados, generó una nueva imagen, visualizando su desplazamiento en la red. Las disponibilidades de esta herramienta son muchas, pero decidí utilizar Prezi Classic porque su sistema es más sencillo y está muy acorde con la manera en la que los pescadores artesanales crean sus cartas de navegación. Esto significa que la manera de crear sus trazados mentales para navegar es muy sencilla para los pescadores, pues hace parte de la transmisión del conocimiento, alimentando su «patrimonio ideológico».

Muchos de los conceptos de navegación, su uso y algunas de sus herramientas, fueron retomados y aplicados en las redes de tecnología para crear la interconexión en la Internet, generando la necesidad y capacidad de expandir los espacios y de tratar de dilatar su dimensión temporal en redes de altas velocidades de la mano de instrumentos tecnológicos 
en la generación de nuevo conocimiento; es decir, podemos crear una carta de navegación en un mar digital para navegar.

\section{Conclusión}

Es posible concluir que la experiencia de revelar los mapas mentales de los pescadores artesanales, a través de dibujos en tinta y grafito sobre papel y luego transferidos a una plataforma digital, evidencia una nueva mirada sobre las cartas de navegación y las historias orales visualizadas en un mar digital.

También se puede decir que las imágenes guardadas en la memoria son fragmentadas; por ello, los pescadores recrean sus faenas de pesca cada vez que las cuentan, agregándoles nuevas ideas con las que enriquecen su imaginario. Cabe agregar que estas recreaciones son el «conocimiento empírico» individual transmitido oralmente y que este pasa a la colectividad fortaleciendo el «patrimonio ideológico».

Esta manera de visualizar los mapas mentales tuvo como propósito el comprender cómo los pescadores artesanales interpretan su mundo y cómo se integran a ese mundo. Pero, más que eso, se busca preservar los mapas mentales que se están perdiendo porque ya son pocos los pescadores que saben marcar dado que los jóvenes no desean aprender ese mecanismo pues dicen que hoy en día hay tantas tecnologías que no necesitan aprender a marcar. Es por ello que estas cartas de navegación, guardadas en la memoria, son reveladas: buscando preservar su «patrimonio ideológico».

También podemos concluir que con la photo-elicitation fue posible verificar las imágenes guardadas en la memoria de los pescadores artesanales. La experiencia de verificar las imágenes con los pescadores fue similar a la de revelar una imagen que va apareciendo en papel fotográfico blanco y negro en un laboratorio de fotografía: el revelar la información de las historias orales fue una gran experiencia tanto para los pescadores artesanales como para el artista investigador, contribuyendo a visualizar esa información guardada.

Además, las imágenes que conforman la infografía son un nuevo modelo de representación de las historias orales. Esto significa que las imágenes mediáticas me llevaron a comprender y preservar «la metáfora de comunicación y movimiento» de los pescadores, al igual que las fotografías y los dibujos muestran un conjunto de escenas y de códigos visuales para visualizar otra forma de lectura de la creación de mapas mentales.

De este modo, la plataforma digital ofreció la oportunidad de ajustar la necesidad de recrear una nueva carta de navegación en la virtualidad, en donde el juego de la estética digital, similar a navegar en un mundo virtual y que simula el mar Caribe colombiano (identificado como un plano en movimiento), generó un nuevo conocimiento desde la estética digital y desde la interactividad.

\section{Agradecimientos}

Ofrezco mis agradecimientos a todos los pescadores artesanales de los pueblos pesqueros artesanales de Old Providence, La Boquilla y Taganga, donde se desarrolló la investigación; a mi director de tesis $\mathrm{PhD}$, Heitor Alvelos, de la Universidad de Oporto, 
Portugal; a los profesores del doctorado de la Universidad de Caldas, en Manizales, Colombia; a los profesores de la Maestría en Estudios del Caribe de la Universidad Nacional sede Caribe; a mi esposa, Susan Leotteau, quien me ayuda con la traducción de los artículos, y al equipo de producción audiovisual del grupo VIDENS, que con sus esfuerzos ha contribuido y fortalecido esta investigación de tesis doctoral.

\section{Referencias}

Bachelard, G. (2000). La poética del espacio. Buenos Aires, Argentina: Fondo de Cultura Económica.

Cantoni, R. C. (2010). relievecontemporaneo.com. Recuperado de https://relievecontemporaneo.com/agua/: www.relievecontemporaneo.com

Garay, J. A. (2005). Informe del Estado de los ambientes marinos y Costeros en Colombia . Santa Marta, Colombia: Litoflash.

García Vargas, O. H. (2007). La cultura humana y su interpretación. Pensamiento \& Gestión, 22. Universidad del Norte, 143-167.

Giannetti, C. (23 de Octubre de 2018). www.mediaartnet.org. Recuperado de http://www.mediaartnet.org/themes/aesthetics_of_the_digital/endo-aesthetics/6/: http://www.artmetamedia.net/

Gómez Alzate, A. (2018). El Pluralismo Cultural Expuesto en el Contexto Académico a partir del Diseño de una Estrategia de Comunicación. Memorias del 17 Festival Internacional de la Imagen (pp. 429-433). Manizales, Colombia: Universidad de Caldas.

Hemingway, E. (1989). El viejo y el mar. Recuperado de https://books.google.com/books?id=5-

lsDwAAQBAJ\&printsec=frontcover\&dq=el+viejo+y+el+mar\&hl=es419\&sa $=$ X\&ved=0ahUKEwio-9S7t5niAhVJu54KHdUVAAQ6AEILjAB\#v=onepage\&q=el\%20viejo\%20y\%20el\%20mar\&f=false

Hernández Carcía, I. C. (2005). Estética, Ciencias y Tecnologías. Creaciones electrónicas y numéricas. Bogotá D.C., Colombia: Pontificia Universidad Javeriana.

Leotteau, F. (2011). El Arte del Caribe colombiano en los XI y XII Salones Regionales de Artes (Tesis de maestría). Universidad Nacional de Colombia, San Andrés Islas, Colombia.

Leotteau, F. (2018). Mapas Mentales de pescadores artesanales en el Caribe colombiano (Tesis de doctorado). Universidad de Caldas, Manizales, Colombia.

Miami, U. O. (2018). Antillean Visions: Maps and The Making of The Caribbean. Miami, United States: NuPress of Miami, Inc.

OIT, Oficina Internacional del Trabajo Ginebra. (2013). https://www.ilo.org/global/publications/lang--es/index.htm. Recuperado el 6 de 
octubre de 2019, de OIT,: https://www.ilo.org/lima/paises/colombia/lang-es/index.htm

Pink, S. (2012). Doing Sensory Ethnographic. California, United States: SAGE.

RAE., D. d. (2014). Diccionario de la lengua española. Recuperado de https://dle.rae.es: dle.rae.es/señal

Varela, F. (2000). Four batons for the future of congnitive science, Envissioning Knowledge. Dumont Colonege: B. Wiens Ed.

Vives de Andrei, J. B. (22 de Diciembre de 1993). Instituto de Investigación Marinas y Costeras. Recuperado de https://www.ecured.cu/Instituto_de_Investigaciones_Marinas_y_Costeras_Jos\%C3 \%A9_Benito_Vives_de_Andr\%C3\%A9is

Wartofsky, M. W. (2016). Estudio de la ciencia. Enciclopedia Gran Omeba. Tomo II. México: Editorial Bibiográfico Omeba. pp. 412-417.

Weisstein, E. W. (09 de octubre de 1995). Recuperado de www.mathworld.wolfram.com. Zambrano, M. (1995). El hombre y lo divino. México: Fondo de Cultura Económica. 